\title{
About the Adjective Based Minimal Structures in the Poem of Dritëro Agolli on the Nature, the Land and the Plants
}

\author{
Msc. Almira Sadikaj \\ Department of Albanian Language, Eqrem Çabej University, Gjirokastër \\ *Corresponding Author: Msc. Almira Sadikaj, Department of Albanian Language, Eqrem Çabej \\ University, Gjirokastër.
}

\begin{abstract}
:
Dritëro Agolli is one of the greatest poets of Albanian literature. He did not break his ties with his homeland, neither physically, nor poetically, artistically, and linguistically. He wrote dozens of poems about the natural environment he came from and wrote so simply and so clearly that he is amazinf, becoming a model and guide for others in this regard. The clarity and simplicity brought with special art, without falling into simplification and stripped of figuration, accompanied him until he wrote the last verse. The poet emphasized that "The poetry necessarily requires a figurative and original verse, a verse where the poet's individuality is felt. I'm not about simplifying poetry, for stripping it from figuration. I am for a poetry in the service of man, in the service of the advancement of society. I do not want its banalization, nor extremism without ideal..."1
\end{abstract}

In the poet's work, this poet easily notes that his language does not know the limitations in the use of words, especially those that were not once called literary and poetic. The poet has also managed to use every word even in poetry. He has raised in popular art, especially the folk lexicon. Jani Thomai writes that for Dritëro "I have been created the feeling of a more folk symbol and representative, in his own self and in his creative work, in behavior and in attitudes. In literary creativity, the folk scent is felt pleasant not only in prose, but also in poetry, which is brought by abudant lexical, phraseological, semantic and syntactic folk instruments. Perhaps it is not necessary to testify to this folk flavor in the Dritëro's poetic discourse, because everyone who dives into his waters immediately senses that within the creator himself there is something that is previously transposed and faithfully transferred to his poetry, but the transposition is the same in the opposite direction: he who reads the literary work of the Dritëro, even in only the poetic discourse, knows Dritëro himself, enters his creative spirit, is convinced that the phenomenon Dritëro is rare for the almost full author's melting with his literary creativity, because the literary production is the author himself in every aspect. He does not pretend and does not need to devise poetry, it stems straight from his heart." ${ }^{2}$

Our article goes away from the whole text, whether in poet's short poetry or poetry consisting of hundreed verses. He pauses in the analyses and linguistic and stylistic interpretations in minimal structures which have an adjecive in their content. Furthermore, knowing that the meaning and the meaning shift of adjectives, as well as the marking and expressive values of the adjectives are not always clearly revealed in these structures (the least in the two-part syntagmas), we have given in all cases the adjective's life in the sentence, in sayings extracted from poetry and which generally come with 2 or more verses. This way the perception of linguistic values in poetry is intertwined with the perception of artistic values, constantly emphasizing not only the stylistics of literary figure, but also the minimal versification structures. All of this, even though at first glance seems to exclude the study of full works in the poetry of our poet, where the adjectives in various poetic functions, especially as epithets of metaphorical value, have caused us to encounter interesting and valuable phenomena and processes for further and in-depth studies.

\footnotetext{
${ }^{1}$ D. Agolli, Të dalim nga qetësia e zakonshme e rutinës, në Dritëro Agolli, "Kam penën e mprehtë, mendjen e kthjellët”, Tiranë, UETPress, Tiranë, 2011, f. 18

2 J. Thomai, Aromë popullore në ligjërimin poetik të Dritëro Agollit, në Dritëro Agolli “Doctor Honoris Causa", Korçë, tetor, 2011
} 


\section{The Study of These STRuCtures Can be Done In SeVeral LineS}

1. Based on the study methodology that the analysis and interpretations, whether they are linguistic or literary, become more complete, more comprehensive and better, if the collected material is grouped and subdivided into thematic fields (also known as lexico- semantic fields), we have made numerous clusters even in the poetry of D. Agolli. The analyses of adjectives in the poetry of this poet are done within the minimal structures /of syntagmas, by lowering the analysis at the level of the two-part structures / syntagmas. The adjective can be a directed part (name + adjective) or leading part (adjective + another part). So these thematic fields include units with adjectives in both these positions, and often the field semantics is determined by both the directed and directing part. In a comprehensive study work of D. Agolli's poetry we have grouped adjectives in over 80 thematic areas, such as:

Fields with minimal structures with adjectives in the poetry, for rigorism, for the father, for mud, for mildness, for savagery, for sagacity, for unfaithfulness, hatred, for loyalty to religion, for plants, for love, for sheep, for pain, for the sun, the craftiness, his family, the women, the brides, the girls, the Moon, the insects, life, for the present time, about Kosovo; Minimal, with adjectives in the poetry for the present day, for horses, for the lake, cow, warfare, flowers, the river, the stream, the cats, the weather, nature, the traveler, the pilgrim, the man, the trees for the fish, for the river, for old age, for politics, for work, for dogs, for the town, for brandy, for the drink, for the friend, for birds, for civic concern, for the evil, for the bad, for beauty, for the good, for the land, the wolf, for death, for the birthplace, for the poet himself, for the wit, for the frustration and for many other fields. Taxonomic divisions in dozens of fields greatly help in the detailed analysis of the adjective of the poet's poetry, but they become a source more likely to be easily used by other researchers and well-wishers of D. Agolli's work, but also of the Albanian language in general.

Following are some adjective-based uses in Dritëro Agolli's poetry about nature, land and plants.

\section{a) The Minimal Structure with Adjectives in the Poetry About Nature}

ashpër (i) $m b$.

Përse ky shkëmb i ashpër dhe i rrudhur,

Që deti e godet, si dash, me valë... (Gdhihet..., f. 132)

brishtë (i, e) $m b$.

Vetëm gjoksi yt $\boldsymbol{i}$ brishtë, aeroport që s'pati mort,

Se m'u dogjën shkrumb e hi të gjithë. (Gdhihet..., f. 293)

Dhe keq më vjen,

Këtë peizazh të brishtë,

Një kalimtar, që helmin ia fsheh kremi. (Gdhihet..., f. 133)

burrac,-e $m b$.

Hesht qiparisi burrac në kodrinë...

Gjyshër, që prehi këtu,

S'e mbusha dot porosinë. (Gdhihet..., f. 152)

çarë (i, e) $m b$.

Nën një shkëmb të zi të çarë,

Të rrethuan me ushtarë. (Gdhihet..., f. 264)

liqentë (i, e) $m b$.

Vagullimi i liqentë bën valë nga kaltërsia

duke kënduar motivin e dashur në festën time

për ditët që $i$ vodha fatit të arratisur. (Gdhihet..., f. 282)

djegur (i, e) $m b$.

Të tjerë fëmijë do pjellin në tokën e djegur,

Edhe më plakat e plakave. (Gdhihet..., f. 121) 
errët (i, e) $m b$.

Ti u shkëpute nga heshtja e përjetshme

e gjirit të errët të tokës. (Gdhihet..., f. 76)

gjallë (i, e) $m b$.

Njeriu zë rritet, zë sheh e mban vesh,

Por fjalën e kemi për barin e gjallë. (Gdhihet..., f. 38)

gjatë (i, e) $m b$.

Përse po këndon i nëmuri gjon,

Në plepat e gjatë? (Gdhihet..., f. 11)

Përsëri në këmbë të kam gjetur,

Ty, moj pishë e pashme shumë e gjatë. (Gdhihet..., f. 13)

Dhe nisej tani drejt një pushimi të gjatë,

Majë Tomorrit diku në burimet. (Gdhihet..., f. 89)

Ky trup i bukur i plepit të gjatë,

Këtu nën shpat, Përpjetë ngrihet i bardhë. (Gdhihet..., f. 242)

gjelbër (i, e) $m b$.

Pas saj si rob i bindur mbeta,

Përditë e prisja tek një shelg,

I madh, i gjelbër me gërsheta,

Qё zbrisnin gjelbër gjer në pellg. (Gdhihet..., f. 118)

Në valët e detit të murrmë,

ciganët për qejfin e tyre kërkojnë lulka moluskesh

dhe degë pishash të gjelbra. (Udhëtoj..., f. 247)

kaltër (i, e) $m b$.

I dua malet e zbehtë me borë,

Në qiell ngjitur si fletë e lëmuar.

Këta të kaltër lumenj pa vaporë,

Ku kurmin tënd e vështroj pasqyruar. (Gdhihet..., f. 189)

kuq (i, e) $m b$.

Si trëndafil i kuq u hap mëngjesi,

Mbi kupën gri të Dajtit të përgjumur. (Gdhihet..., f. 156)

Dhe hëna mbi male e kuqe rri pezull,

Si kokë e një dashi e gatshme të piqet. (Gdhihet..., f. 256)

murrm/ë (i), -e(e) $m b$.

Mëngjesi hapet, skuqet qielli i murrmë,

Lëshon poeti dorën përmbi letër. (Gdhihet..., f. 73)

shkretë (i, e) $m b$.

Dita ra në hon të shkretë,

Malit gunë i veshën retë. (Gdhihet..., f. 264)

zinj (e) $m b$.

Vështrova nga malet e zinj me samarë,

Dhe plot trishtim i thashë tim eti... (Gdhihet..., f. 175)

b) The Minimal Structure with Adjectives in the Poetry for the Earth

përjetsh/ëm (i), -me (e) $m b$.

Ti u shkëpute nga heshtja e përjetshme

e gjirit të errët të tokës. (Gdhihet..., f. 76) 
përmjerë (i, e) $m b$.

Siç mbyllin plot e plot të tjerë.

Disa mendojnë: u fut ndër yjtë,

Disa në tokën e përmjerë...(Gdhihet..., f. 245)

c) The Minimal Structure with Adjectives in the Poetry for Trees

lakuriq-e, $m b$.

Vrapon një vrull harabelësh,

Mes thatësirës së tokës dhe pemëve lakuriqe.

lashtë (i, e) $m b$.

Ky trup i lashtë $i$ ullirit,

U rrudh, u krus, $u$ sfilit. (Gdhihet..., f. 163)

madh (i), -e (e) $m b$.

Dhe këngë pastaj nëpër male të ngrenë,

Pёr тиа, për rrapin e madh me litar. (Gdhihet..., f. 145)

Molla ish e madhe dhe me vjershën,

Mbushej plot siç mbushet globi i botës. (Gdhihet..., f. 144)

mendjemadh,-e $m b$.

Ah, ky plep si princi mendjemadh,

Çizmen e ka mbathur dhe qëndron,

Mes kësaj dëbore që ende zbardh. (Gdhihet..., f. 143)

Dhe mbi çizme heshtur i pikon,

Ah, nga loti princi mendjemadh. (Gdhihet..., f. 143)

pash/ëm, -me (e) $m b$.

Përsëri në këmbë të kam gjetur,

Ty, moj pishë e pashme shumë e gjatë. (Gdhihet..., f. 13)

\section{d) The Minimal Structure with Adjectives in the Poetry for Flowers}

bardhë (i) $m b$.

Dhe trëndafili $\boldsymbol{i}$ bardhë fsheh spicat,

Fletëve të dendura nën kurorat me palë... (Gdhihet..., f. 89)

bukur (i, e) $m b$.

Ky trup i bukur i plepit të gjatë,

Këtu nën shpat,

Përpjetë ngrihet $\boldsymbol{i}$ bardhë. (Gdhihet..., f. 242)

heshtur (i, e) $m b$.

I lemë të heshtura lulet në sallon, Çudi!

Na duket se ndiejmë,

Si lulja me lulen qetësisht kuvendon. (Gdhihet..., f. 302)

e) The Minimal Structure With Adjectives In The Poetry For The Grass

brishtë (i, e) $m b$.

Atdhe, të ndiej edhe në zhurmën e rrapit të lashtë,

Edhe në fijen e brishtë të barit. (Udhëtoj..., f. 17)

prerë $(\mathrm{i}, \mathrm{e}) m b$.

Se ndodh me këngën ndonjëherë,

që s'është e drejtpërdrejtë: 
përsipër nxjerr një bar të prerë,

në rrënjët i fut retë; (Baladë..., f. 95)

Dhe kishte bar, po bar të prerë,

Se s'rritnin dheun luginat. (Baladë..., f. 123)

vjetër (i, e) $m b$.

Rrodhi në lajthi,

$U$ tha bar i vjetër,

Doli bar i ri... (Dhjetë Sy, f. 67)

njomë (i, e) $m b$.

Rrëzë portës sonë,

Vjen e puth një valë,

Barin aq të njomë. (Dhjetë Sy, f. 67)

Mirë (i, e) Tagji m'i vuri kalit,

E bar nga më të mirët,

E mori nga qilari,

Që kish për mysafirët. ("Në rrugë dola”, Poezi, f. 25)

The examples are hundreds but we were sufficed with these.

2. The minimal structures with adjectives or syntagms with an adjective part in the poetry of Dritëro Agolli can be analyzed morphologically, focusing on two aspects: the morphological affiliation of the leading parts of these structures / syntagms and the phenomena of the word formation of adjectives as the part of these constructions.

3. These structures can be studied also syntaxically, focusing on the syntactic function of a given adjective. Here we encounter some examples:

a) In the structures with adjective in the poetry of Dritëro Agolli on nature, land or plants we encounter dozens of cases when the adjective emerges in the predicative function, especially as part of the noun predicate (when together with the verb 'këpujë' builds a predicate of this type). In this case the head of the syntagma is double, the adjective is led by the noun and the verb.

Molla ish e madhe dhe me vjershën,

Mbushej plot siç mbushet globi i botës. (Gdhihet..., f. 144)

b) Adjective can emerge as a predicate determinant. Even in this case, the head of the syntagma is double, the adjective is led by the noun and the verb. This double dependence of the adjective appears even when it comes out as the subject predicate, even when it comes out as the object predicate.

- Adjective as an object predicate:

Ky trup i bukur i plepit të gjatë,

Këtu nën shpat,

Përpjetë ngrihet i bardhë. (Gdhihet..., f. 242)

- Mbiemri si kallëzuesor i kundrinorit:

I lemë të heshtura lulet në sallon, Çudi!

Na duket se ndiejmë,

Si lulja me lulen qetësisht kuvendon. (Gdhihet..., f. 302)

4. The minimal structures with adjectives or syntagms with an adjective part in the poetry of Dritëro Agolli can also be analyzed in the plane of figurative uses and semantic transformations. These uses indicate that in poetry we can often be with one foot in the figurative use of an adjective/ lexical unit and with one foot in the figurative meaning of this unit. The academician Jani Thomai 
has distinguished between these two different concepts. He emphasizes that "It is necessary to distinguish between the figurative use and the lexical meaning of the word... The figurative use of the word is an instrument of literary stylistics, distinguished for emohasized emotional coloration, there is no wide spread in the speakers of the language and it is not obligatory for everyone, sometimes it is the creation of an author and often remains within his work. The words are figuratively used for items, qualities, or actions that have their own direct designations." ${ }^{3}$

He emphasizes that "There is a boundary between the figurative use of the word and the lexical meaning, which also indicates the boundary between literary stylistics and linguistic stylistics. That boundary is not categorical and insurmountable, because lexical meanings arise from the figurative uses of words. The emergence of a new meaning in a word generally goes through a comparison. The path is: from comparison to metaphor, from metaphor to lexicalization, when emotional coloration begins to disappear, when this usage becomes general, consistent, and mandatory for language speakers." 4

a) In Dritëro Agolli's poetry one finds minimal structures with adjectives with comparison (Unë ul kokën dhe buzët vë në burim, / Pi si një kafshë nate e egër, / Dhe uji ujit trupin tim, /Si luginën e gjelbër.); with hyperbole (..çdo gur e bëra të bleruar, se shpirtin tim i dhashë); with antithesis (Diçka treti mollë e shkurtër, Diçka humbi plep $\boldsymbol{i}$ gjatë...), as you find structures with personification; with figurative parallelism, with litotes etc.

b) Minimal structures with adjectives in the poetry for nature, land plants, etc., can be seen also according to the figures of words. We have hundreds and hundreds of units with uses as epithets (Këto mollë të rënda,/ kjo rrugë me pluhur të artë.); me metaforë (Hënë $\boldsymbol{e}$ kallajisur tok me yjtë, / Panë si kërcejnë valle gjinjtë.... Sa keq që kali i murrmë i erës,Ty nuk të shpuri dot.) etc.

5. The minimal structures with adjective can also be seen according to semantic relations. The emergence of a new meaning in the structure of a word implies the vertical enrichment of the language lexicon, a process otherwise known as the polysemic process. The academician Jani Thomai emphasizes that "Expanding the understanding structure of words is enrichment for the lexicon, it is one of the inner ways of increasing the expressive force of language. In this view, every new meaning that is born is the same as any newly formed word. However, the agreement is not difficult, because the words are used in speech related to other words, thus creating contexts within which each word brings about only one of its meanings."

We are presenting usages in the minimal structures of the adjectives in the poetry of Dritëro Agolli according to semantic relations, referring to literary stylistics: The synonym minimal structure (Në fillim e imët, si degë panje e lagur, / Vjen dita e brishtë, e mekët, e zbehtë, / Vështron në dritare, kalon e drojtur pragun, E dobët, e mitur, e lehtë.); antonymic structure (Blerimi i gjelbër i grurit dhe pjekja e tij e florinjtë), structures with enumeration (Vreshta duket, / Si grua, / E porsadalë nga materniteti: / E pafuqishme, / E lodhur, / E qeshur) etc.

Dritëro Agolli also uses many poetic pronounciation figures, such as apostrophes and exclamations (Obo-bo mullar, ç'të panë sytë, / Obo-bo ti kashta e florinjtë); Structure with consonance (Atdhe, të ndiej edhe në zhurmën e rrapit të lashtë, Edhe në fijen e brishtë të barit) etc.

Finally, we emphasize that Dritëro Agolli is not only one of the most prominent contemporary writers in Albanian literature but the literary language of his literary work has direct and multiple links to the standard Albanian lexicon. We can say that almost the entire language is part of its normative lexicon. This implies that even the paradigmatic group of adjectives derived from his poetic work is an integral part of this lexicon.

\footnotetext{
${ }^{3}$ J. Thomai, Aromë popullore në ligjërimin poetik të Dritëro Agollit, në Dritëro Agolli "Doctor Honoris Causa", Korçë, tetor, 2011

${ }^{4}$ J. Thomai, Leksikologjia e gjuhës shqipe, Tiranë, 2008, f. 126-127

5 J. Thomai, Leksikologjia e gjuhës shqipe, Tiranë, 2008, f. 128-129
} 


\section{REFERENCES}

[1] Dritëro Agolli, Të dalim nga qetësia e zakonshme e rutinës, në Dritëro Agolli, "Kam penën e mprehtë, mendjen e kthjellët", Tiranë, UETPress, Tiranë, 2011

[2] Jani Thomai, Aromë popullore në ligjërimin poetik të Dritëro Agollit, në Dritëro Agolli "Doctor Honoris Causa", Korçë, tetor, 2011

[3] Jani Thomai, Leksikologjia e gjuhës shqipe, Tiranë, 2008

\section{Harvested works:}

Dritëro Agolli, “Gdhihet dhe ngryset”, 2000

Dritëro Agolli, "Në rrugë dola”, në vëllimin "Poezi", 1979

Dritëro Agolli, “Dhjetë Sy”, 1985

Dritëro Agolli, "Baladë për tim atë dhe për vete”, 1997

Dritëro Agolli, “Udhëtoj i menduar”, 1985

\section{AUTHOR'S BIOGRAPHY}

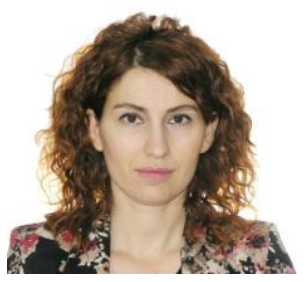

Name / Surname: $\quad$ Msc. Almira Sadikaj

Date of birth: 06.03 .1985

Email address:

almira.sadikaj@gmail.com

University of Gjirokastra: Faculty of Education and Social Sciences,. Department: Department of Albanian Language

Teaching subject / Field of study (for staff of institutes or research centers) Teaching subject: Morphology (Foreign languages), Ethnolinguistics, Phonetics, Standard language history.

Scope of study: Grammar

Undergraduate Studies: University of Gjirokastra, Faculty of Education and Social Sciences, Branch: Albanian Language and Literature, Period of study: 04.10.2004-05.07.2008,

Postgraduate Studies: University of Tirana, Faculty of History and Philology , Theme: Primary Surnames in "Albanian Language Forum 2006", Leader: Prof. dr. Ethem Likaj, Period: 26.10.2009 19.04.2012

PHD / Doctor of Science: $\mathrm{In} \mathrm{PhD}$ thesis

Citation: Msc. Almira Sadikaj, About the Adjective Based Minimal Structures in the Poem of Dritëro Agolli on the Nature, the Land And the Plants, International Journal of Humanities Social Sciences and Education (IJHSSE), vol 4, no.9, 2017, pp. 1-7. doi:dx. doi.org/10.20431/2349-0381.0409001.

Copyright: (C) 2017 Authors. This is an open-access article distributed under the terms of the Creative Commons Attribution License, which permits unrestricted use, distribution, and reproduction in any medium, provided the original author and source are credited. 